\title{
Penerapan Anggaran Berbasis Kinerja Pada Dinas Kesehatan Kota Bandung
}

\author{
${ }^{1}$ Supyani, ${ }^{2}$ Khaerul Umam \\ ${ }^{1}$ UIN Sunan Gunung Djati Bandung, Indonesia; Supyanisupi@gmail.com \\ ${ }^{2}$ UIN Sunan Gunung Djati Bandung, Indonesia; Umam@uinsgd.ac.id
}

\begin{abstract}
This journal discusses the application of performance-based budgeting at the Bandung City Health Office. The budgeting process at government agencies currently uses a performance-based budgeting approach. This study aims to determine the implementation of performance-based budgeting at the Bandung City Health Office by looking at inhibiting factors in the implementation of performance-based budgeting, as well as knowing the steps that have been taken by the Bandung City Health Office in overcoming budgeting problems. The results of this study indicate the application of performance-based budgeting at the Bandung City Health Office has been carried out in a clear, relevant, economic, adequate and monitorable manner. However, the implementation is still not optimal, this is due to the lack of available budget, the existence of collaborative tasks with other agencies and the lack of information support provided by health workers. Barriers come from internally such as lack of available budget and come from externals such as changes in the economic and social environment that cause changes in prices and changes in disease patterns.
\end{abstract}

Keywords: Local Government, Public Agency, Policy Implementation, Performance-Based Budgeting

\section{Pendahuluan}

Pengelolaan keuangan pemerintah merupakan salah satu tanggung jawab pemerintah daerah atau instansi dalam menjalankan roda pemerintahannya. Dewasa ini proses penyusunan keuangan daerah telah beralih dari konsep anggaran tradisional kepada konsep new public management yang lebih menekankan kepada kinerja bukan kebijakannya. Sementara itu anggaran sebagaimana dijelaskan oleh (Harun, 2009) berpendapat bahwa anggaran merupakan perencanaan resmi atas aktivitas atau tindakan yang dinyatakan dalam bentuk uang (Monetary Term). Dalam perspektif publik, anggaran diartikan sebagai pernyataan kuantitatif dari perencanaan badan-badan pemerintah yang dinyatakan dalam bentuk fisik maupun dalam bentuk keuangan, ataupun dalam bentuk keduanya. Dalam proses perencanaan dan penganggaran pada instansi pemerintah saat ini menggunakan pendekatan anggaran berbasis kinerja sesuai dengan Pasal 4 Peraturan Pemerintah Nomor 21 Tahun 2004 tentang Rencana Kerja dan Anggaran Kementerian Negara/Lembaga (RKA-KL).

Konsep anggaran berbasis kinerja ini tentu menjadi harapan baru dalam berlangsungnya kegiatan keuangan agar berjalan secara efektif dan efisien. Anggaran berbasis kinerja lahir sebagai salah satu perbaikan terhadap proses penganggaran tradisional yang masih terdapat beberapa kelemahan dalam pelaksanaan anggarannya, seperti belum terdapatnya tolak ukur kinerja yang baku dalam pelaksanaannya. Konsep anggaran berbasis kinerja atau biasa disebut dengan performance-based budgeting merupakan suatu konsep penganggaran yang berorientasi pada output organisasi. Dengan adanya penyusunan anggaran berbasis kinerja ini diharapkan adanya peningkatan efisiensi pengalokasian sumber daya dan adanya efektivitas penggunaan anggaran sesuai dengan perencanan yang telah ditetapkan oleh pemerintah daerah. 
Dinas Kesehatan Kota Bandung merupakan salah satu Satuan Kerja Perangkat Daerah (SKPD) pada lingkup pemerintahan Kota Bandung yang telah menerapkan sistem anggaran berbasis kinerja dalam pelaksanaan urusan keuangannya. Lebih lanjut, dengan berlakunya Peraturan Menteri Keuangan No. 258/PMK.02/2015 terdapat persentase minimum yang harus dipenuhi oleh Satuan Kerja Perangkat Daerah dalam pelaksanaan anggarannya. Adapun persentase minimum yang harus dipenuhi yaitu sebesar 95\% dari anggaran yang telah dianggarkan sebelumnya. Namun pada kenyataannya, berdasarkan data awal yang didapat penulis dari LAKIP Dinas Kesehatan Kota Bandung (https://dinkes.bandung.go.id) terdapat realisasi atau penyerapan yang rendah dari anggaran yang telah dianggarkan sebelumnya dan juga masih terdapat capaian kinerja yang belum tercapai sepenuhnya, seperti berikut ini:

\section{Diagram 1}

\section{Realisasi Anggaran Belanja Dinas Kesehatan Kota Bandung}

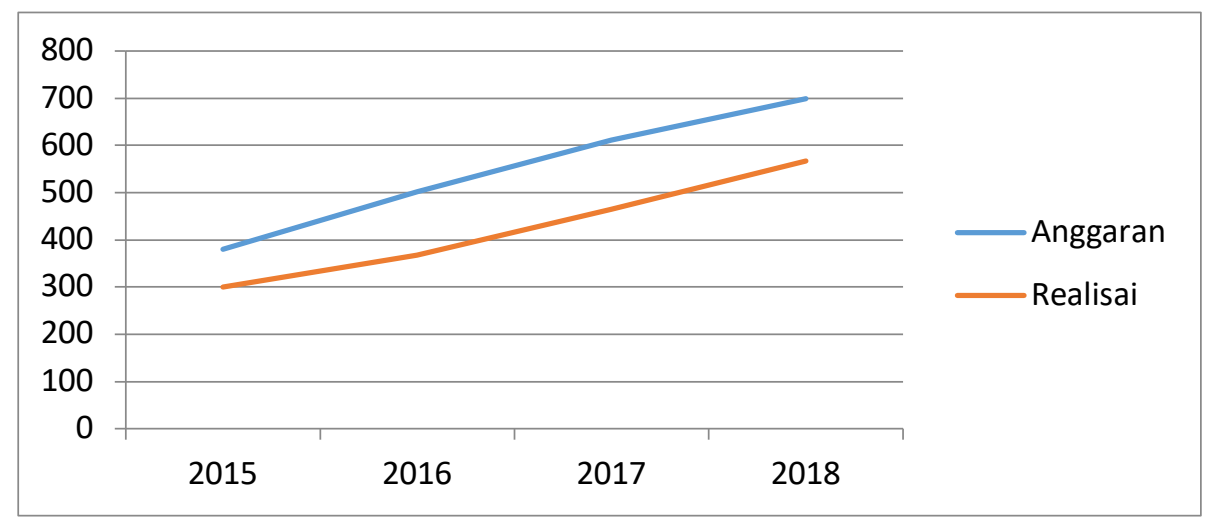

Sumber: LAKIP Dinkes Kota Bandung 2016-2018

Berdasarkan diagram 1 di atas menunjukan persentase realisasi anggaran Dinas Kesehatan Kota Bandung belum mampu mencapai anggaran yang telah ditetapkan. Untuk realisasi belanja tahun 2016 mengalami penurunan yang cukup signifikan dari tahun sebelumnya, namun secara pertumbuhan anggarannya dari tahun 2016-2018 selalu terdapat kenaikan dalam jumlah anggaran. Selain masih terdapat rendahnya angka realisasi anggaran, masih terdapat target indikator kinerja utama yang belum tercapai secara optimal, seperti yang dijelaskan pada tabel berikut ini:

\section{Tabel 1}

\section{Realisasi Capaian Kinerja Indikator Kinerja Utama}

Dinas Kesehatan Kota Bandung

\begin{tabular}{clccc}
\hline No & \multicolumn{1}{c}{ Indikator } & $\begin{array}{c}\text { Target } \\
2018\end{array}$ & $\begin{array}{c}\text { Realisasi } \\
2018\end{array}$ & $\begin{array}{c}\text { Capaian } \\
\text { Kinerja }\end{array}$ \\
\hline 1 & Angka kematian ibu & 64,9 & 75,3 & 84,00 \\
\hline 2 & Angka kematian bayi & 27,8 & 23,8 & 114,38 \\
\hline 3 & Persentase balita gizi buruk & 0,38 & 0,38 & 100,00 \\
\hline \multicolumn{4}{c}{ Sumber: LAKIP Dinkes Kota Bandung 2016-2018 }
\end{tabular}

Dengan beberapa permasalahan mengenai rendahnya angka realisasi anggaran belanja maupun realisasi kinerjanya, perlu dilihat dalam penerapan anggaran berbasis kinerjanya. Permasalahan penganggaran juga dijelaskan dalam LAKIP Dinas Kesehatan Kota Bandung tahun 2016-2018 yang menunjukan masih terdapatnya proses penganggaran dan perencanaan 
yang belum optimal. Tentu dengan adanya hal ini, penulis merasa penting untuk melakukan penelitian mengenai penerapan anggaran berbasis kinerja pada Dinas Kesehatan Kota Bandung. Penelitian mengenai bagaimana penerapan anggaran berbasis kinerja, apakah ada kendala dalam penerapan anggaran berbasis kinerja sehingga menyebabkan rendahnya angka realisasi anggaran dan realisasi kinerja serta untuk melihat upaya yang telah dilakukan oleh instansi terkait dalam mengatasi permasalahan tersebut.

Anggaran berbasis kinerja sendiri sebagaimana dijelaskan oleh (Bastian, 2010) bahwa anggaran berbasis kinerja diartikan sebagai suatu sistem penganggaran yang memiliki hubungan yang erat dengan pencapaian visi, misi serta rencana strategis dari suatu organisasi yang keseluruhannya berorientasi pada output organisasi. Anggaran berbasis kinerja diartikan sebagai sistem penganggaran bagi manajemen untuk mengaitkan setiap pendanaan yang dituangkan dalam kegiatan-kegiatan dengan output dan outcome yang diharapkan termasuk efisiensi dalam pencapaian output dan outcome tersebut (Halim, 2007). Anggaran berbasis kinerja juga dijelaskan oleh (Robinson \& Last, 2009) bahwa anggaran berbasis kinerja dimaksudkan untuk meningkatkan efisiensi dan efektivitas pengeluaran publik dengan menghubungkan pendanaan organisasi sektor publik dengan hasil yang mereka berikan, membuat penggunaan sistematis informasi kinerja.

Penyusunan anggaran ini diharapkan dapat meningkatkan keberhasilan program, baik dari sisi pelaksanaan maupun perencanaan. Pada dasarnya anggaran berbasis kinerja disusun untuk mengurangi kelemahan yang terjadi dalam sistem penganggaran tradisional, yang disebabkan oleh tidak adanya tolak ukur yang digunakan sebagai alat untuk mengukur kinerja dalam proses pencapaian tujuan dan sasaran pelayanan publik. Penganggaran berbasis kinerja diawali dengan proses perencanaan program serta penyusunan struktur organsasi yang sesuai dengan program kerja tersebut (Mardiasmo, 2009). Konsep mengenai anggaran berbasis kinerja juga dijelaskan oleh (Nordiawan \& Hertianti, 2010) tentang kriteria indikator kinerja yang dapat digunakan dalam penganggaran berbasis kinerja seperti berikut ini:

1. Clear, berarti indikator kinerja yang digunakan harus jelas dan dapat dipahami supaya tidak terjadi malinterpretasi.

2. Relevant, berarti indikator yang digunakan mesti mempunyai persamaan serta hubungan dengan tujuan yang direncanakan dengan tujuan yang akan dicapai.

3. Economic, berarti dana yang digunakan sebagai indikator yang dibutuhkan harus berada dalam posisi harga yang wajar (tidak mahal biayanya).

4. Adequate, berarti indikator kinerja dapat digunakan untuk menilai kinerja. Apakah indikator yang satu dapat dikombinasikan dengan indikator lainnya dan dapat digunakan untuk menilai kinerja.

5. Monitorable, berarti indikator kinerja dapat diperbaiki apabila penyempurnan memang diperlukan. Dengan demikian, maka evaluasi serta masukan dalam rangka peningkatan kualitias indikator sangat dibutuhkan.

Dengan adanya penganggaran dan perencanaan yang baik tentu akan mendukung proses pelaksanaan anggaran yang baik pula. Karena pada dasarnya penganggaran dan perencanaan merupakan ilustrasi dari apa yang akan dilakukan ke depannya. Penelitian mengenai penerapan anggaran berbasis kinerja telah banyak dilakukan sebelumnya, namun kebanyakan penelitian yang dilakukan lebih menekankan terhadap pengaruh dari anggaran berbasis kinerja bukan menekankan terhadap sisi penerapannya seperti penelitian yang dilakukan oleh (Dwiputrianti \& Suharsini, 2012.) yang melakukan penelitian mengenai Analisis Penerapan Anggaran Berbasis Kinerja (ABK) Terhadap Efisiensi, Efektivitas dan 
Akuntabilitas pada Pusat Pendidikan dan Pelatihan Kementrian Dalam Negeri Regional Bandung.

(Tinangon, et al, 2015.) melakukan penelitian mengenai Penerapan Anggaran Berbasis Kinerja untuk Menunjang Akuntabilitas Publik pada Badan Lingkungan Hidup Kota Manado, namun menggunakan tolok ukur penelitian yaitu Undang-Undang Nomor 17 Tahun 2003. Kemudian (Ningsih et al, 2019) melakukan penelitian mengenai anggaran berbasis kinerja dengan judul Analisis Penerapan Anggaran Berbasis Kinerja dengan Konsep Money Follow Program dalam Perencanaan dan Penganggaran Kota Padang, sedangkan tolok ukur yang digunakan penulis pada penelitian ini menggunakan teori yang dijelaskan oleh (Nordiawan \& Hertianti, 2010) mengenai kriteria indikator kinerja yang baik dalam penganggaran berbasis kinerja. Dari penjelasan mengenai latar belakang masalah tersebut maka penulis tertarik untuk melakukan penelitian yang bertujuan untuk mengetahui proses penerapan anggaran berbasis kinerja pada Dinas Kesehatan Kota Bandung? serta melihat apakah terdapat kendala dalam penerapannya? Jika memang terdapat kendala apa upaya yang telah dilakukan oleh instansi terkait dalam mengatasi kendala tersebut?

\section{Metode Penelitian}

Pada penelitian ini penulis akan menggunakan pendekatan penelitian kualitatif dengan metode penelitian deskriptif, karena penulis akan mendeskrifsikan satu variabel dependen dengan data-data yang berbentuk kualitatif. Penelitian deskriptif sebagaimana dijelaskan oleh (Anggara, 2015), bahwa suatu metode penelitian yang menjelaskan sesuatu yang menjadi sasaran penelitian secara mendalam. Ini berarti penelitian tersebut dilakukan dalam rangka mengungkap segala sesuatu dan berbagai aspek dari sasaran penelitian tersebut. Sedangkan pendekatan kualitatif sebagaimana dijelaskan oleh (Silalahi, 2012) merupakan Suatu proses penyelidikan yang digunakan dalam memahami permasalahan sosial yang didasarkan pada penggambaran holistik lengkap yang dibentuk dengan kata-kata, melaporkan informasi dari informan secara terperinci, dan disusun dalam sebuah latar alamiah.

Teknik pengumpulan data yang digunakan oleh penulis meliputi observasi yang dilakukan pada Kantor Dinas Kesehatan Kota Bandung, wawancara yang dilakukan dengan narasumber yang memiliki informasi mengenai penerapan anggaran berbasis kinerja pada instansi terkait yang meliputi: 1) Kepala Sub Bagian Program Data dan Informasi 2) Kepala Bidang Sumber Daya Kesehatan 3) Kepala Bidang Pencegahan dan Pengendalian Penyakit Menular 4) PPTK Bidang Pelayanan Kesehatan 5) PPTK Bidang Kesehatan Masyarakat 6) PPTK Sub Bagian Keuangan dan studi dokumentasi yang meliputi LRA yang didapat dari instnasi terkait serta informasi dan dokumen lainnya yang ada pada web resmi Dinas Kesehatan Kota Bandung. Sedangkan teknik analisis data yang digunakan merupakan teknik triangulasi yang meliputi reduksi data, penyajian data serta penarikan kesimpulan.

\section{Hasil dan Pembahasan}

\section{a. Penerapan anggaran berbasis kinerja pada Dinas Kesehatan Kota Bandung}

Penerapan anggaran berbasis kinerja menjadi salah satu pendekatan dalam proses penganggaran dalam pemerintahan Indonesia. Pendekatan ini digunakan dalam rangka meningkatkan kinerja dari pemerintah, karena dengan digunakannya anggaran berbasis kinerja berarti ada tolok ukur kinerja yang di tergetkan oleh pemerintah. Menurut (Nordiawan \& Hertianti, 2010) ada 5 kriteria yang baik dalam menyusun indikator kinerja dalam 
penganggaran berbasis kinerja, kelima kriteria ini meliputi Clear, Relevant, Economic, Adequate dan Monitorable (CREAM).

Pada Dinas Kesehatan Kota Bandung sendiri telah melaksanakan penganggaran berbasis kinerja secara clear, relevant, economic, adequate dan monitorable, namun belum berjalan secara optimal. Hal ini ditandai dengan masih terdapat beberapa kajian yang belum berjalan secara optimal. Pertama, proses penyusunan indikator kinerja telah disusun sejelas mungkin sehingga dapat dipahami oleh seluruh pegawai. Indikator kinerja yang digunakan pun telah disusun dalam bentuk kualitatif dan kuantitatif yang berarti indikator kinerja dinyatakan dalam bentuk program kerja kegiatan serta program kerja anggaran. Proses perencanaan indikator kinerja yang digunakan dibahas secara bersama-sama dalam penetapan rencana strategis organisasi. Bahkan proses perencanaan yang ada dilakukan mulai dari tingkat bawah sehingga membuat pegawai dapat berperan aktif dalam penentuan kegiatan yang akan dilaksanakan pada periode tersebut. Kejelasan mengenai indikator kinerja yang digunakan tentu perlu diperhatikan, hal ini berhubungan dengan kemampuan para pegawai dalam memahami mengenai indikator yang ada sehingga tidak akan menimbulkan malinterpretasi diantara mereka.

Selanjutnya proses penyusunan indikator kinerja yang digunakan telah disusun berdasarkan tujuan organisasi dan rencana strategis yang ada serta memiliki hubungan antara tujuan yang direncanakan dengan tujuan yang hendak dicapai. Proses penyusunan indikator kinerja telah didasarkan pada tujuan organisasi, sehingga indikator kinerja yang disusun merupakan salah satu usaha dalam mencapai tujuan yang telah ditentukan sebelumnya. Indikator kinerja yang digunakan pun memiliki hubungan dengan visi dan misi dari Dinas Kesehatan Kota Bandung, yang dapat dilihat dari indikator kinerja utama Dinas Kesehatan Kota Bandung. Namun memang pada praktiknya belum berjalan secara optimal. Pada pelaksanaannya masih terdapat beberapa kendala yang dihadapi seperti kurangnya anggaran yang tersedia sehingga membuat kegiatan dalam rangka pencapaian tujuan tersebut terhambat, karena kegiatan yang akan dilakukan direncanakan dan dilaksanakan berdasarkan anggaran yang tersedia. Kemudian adanya beberapa kegiatan dalam rangka pencapaian tujuan yang hendak dicapai, tugas dan wewenang dan wewenangnya ada pada instansi lain. Hal ini juga membuat kegiatan terhambat, tentu hal ini harus diimbangi dengan koordinasi yang baik dalam menjalankan tugas kolaboratif semacam ini guna meningkatkan kinerja yang lebih baik lagi.

Kemudian, proses penyusunan indikator kinerja yang ada pada Dinas Kesehatan Kota Bandung telah didasarkan atas standar satuan harga (SSH) yang berlaku pada seluruh SKPD yang ada pada Pemerintah Kota Bandung. Proses penyusunan standar harga ini dilakukan oleh Badan Perencanaan Pembangunan, Penelitian, dan Pengembangan (Bappelitbang) Kota Bandung, yang kemudian disosialisasikan kembali kepada seluruh instansi yang ada pada Pemerintah Kota Bandung. Jadi, ketika saat perencanaan dan penganggaran hanya perlu memasukan item belanja yang perlu dibiayai, kemudian akan muncul standar harga yang ada dan itulah yang akan menjadi anggaran dalam melaksanakan program. Sementara itu untuk beberapa item belanja yang belum termasuk di dalam standar satuan harga nantinya akan diusulkan oleh instansi terkait kepada Bappelitbang, sehingga item belanja yang dimaksud akan tertera dalam standar satuan harga pada periode selanjutnya. Kemudian penyusunan indikator kinerja juga didasarkan atas harga perhitungan sendiri (HPS) yang diperoleh dari harga survei atas barang dan jasa yang ada di pasaran, sedangkan untuk kegiatan yang berhubungan dengan pengadaan barang dan jasa dalam pelaksanannya mengikuti petunjuk teknis mengenai pengadaan barang dan jasa. Kemudian, untuk pendanaan dari Dana Alokasi Khusus (DAK) yang bersumber dari APBN juga menggunakan petunjuk teknis mengenai penggunaan dana dari APBN. 
Selanjutnya indikator kinerja yang disusun dapat menilai kinerja serta dapat dikombinasikan dengan indikator lain dalam menilai kinerja instansi terkait. Indikator kinerja yang disusun telah dapat menilai kinerja, dan proses penilaian kinerja yang ada pada Dinas Kesehatan Kota Bandung dapat dilihat dari dua aspek, pertama dapat dilihat dari ketercapaian program dengan realisasinya dan kedua dilihat dari ketercapaian anggaran dengan realisasinya. Kedua aspek kinerja tersebut harus dapat dipenuhi realisasinya pada tahun terkait untuk memenuhi kinerja yang diharapkan. Hal utama dalam menilai kinerja yang ada disesuaikan dengan target dari program kerja kegiatannya dan itu harus mampu dipenuhi oleh instansi tersebut, sedangkan untuk realisasi dari kinerja anggaran sering kali tidak sesuai dengan apa yang direncanakan, hal ini dapat dimaklumi apabila terjadinya efisiensi dan target kinerjanya tercapai. Sedangkan untuk indikator kinerja yang di gunakan telah disusun sebaik mungkin dan telah dirumuskan bersama dengan pembahasan Renstra, sehingga tentu dengan hal ini instansi terkait harus mampu memenuhi kinerja indikator yang telah disusun sebelumnya guna mendapatkan penilaian yang baik bagi instansi tersebut.

Kemudian, proses penyempurnaan indikator kinerja yang digunakan dapat disempurnakan apabila penyempurnaan memang dibutuhkan. Untuk indikator kinerja yang digunakannya sendiri merupakan suatu hasil dari proses monitoring dan evaluasi yang dilakukan. Proses monitoring dan evaluasi sendiri telah dilakukan secara berkala setiap triwulan sekali, bahkan dilakukan dari tingkat bawah sampai ke tingkat atas. Proses ini juga dilakukan baik oleh internal yang meliputi kontrol yang dilakukan oleh Sub Bagian Program Data dan Informasi maupun kontrol yang dilakukan pada bidang-bidang yang ada melalui masing-masing PPTK maupun kontrol yang dilakukan oleh eksternal seperti inspektorat dan badan pemeriksa keuangan, kemudian kegiatan monitoring dan evaluasi ini telah terhubung dengan pemerintah daerah lewat SIMDA. Namun proses monitoring yang ada masih mengalami beberapa hambatan dalam pelaksanaannya seperti masih kurangnya dukungan informasi yang diberikan oleh pelayan kesehatan dalam memenuhi target indikator kinerja utama yang ada pada instansi tersebut, sehingga membuat proses kontrol yang dilakukan belum berjalan dengan optimal.

Dari hasil pemaparan materi mengenai kajian dari anggaran berbasis kinerja dengan beberapa parameter yang digunakan sebagimana telah di paparkan sebelumnya di atas, dapat di lihat bahwa proses penerapan anggaran berbasis kinerja pada Dinas Kesehatan Kota Bandung telah di jalankan secara Clear, Relevant, Economic, Adequate dan Monitorable, namun ada beberapa aspek yang belum berjalan dengan optimal, aspek tersebut meliputi kajian relavant dan kajian monitorable. Sedangkan jika dibandingkan dengan penelitian terdahulu yang penulis gunakan sebagai bahan acuan, penelitian ini memiliki persamaan dengan penelitian terdahulu yang penulis gunakan sebagai acuan yaitu penerapan anggaran berbasis kinerja telah dijalankan sesuai dengan kajian teori yang digunakan dalam melihat penerapan anggaran berbasis kinerja meskipun dengan menggunakan kajian teori yang berbeda. Namun penelitian ini memiliki perbedaan dengan hasil yang di dapat dari penelitian terdahulu yang penulis gunakan, jika dilihat dari beberapa penelitian tersebut penerapan anggaran berbasis kinerja telah dilaksanakan dengan baik dan benar sesuai dengan kajian teorinya masingmasing. Dalam penelitian ini meskipun penerapan anggaran berbasis kinerja telah disesuaikan dengan kajian teori yang digunakan yaitu telah disusun secara clear, relevant, economic, adequate dan monitorable namun pada pelaksanaannya masih terdapat beberapa kajian yang belum dilaksanakan secara optimal.

Hal ini terdapat pada kajian relevansi antara indikator kinerja yang digunakan dengan tujuan yang ada dan hendak dicapai, hasil penelitian ini menunjukan bahwa ada beberapa permasalahan yang ditemui seperti kurangnya anggaran yang di dapat sehingga belum semua kegiatan dapat dilaksanakan secara maksimal dalam rangka pencapaian tujuan yang hendak 
dicapai. Kemudian ada tujuan yang hendak dicapai namun dalam pelaksanaan wewenangnya ada pada OPD lain atau disebut juga dengan tugas kolaboratif, tentu hal ini menuntut adanya koordinasi yang dilakukan dengan instansi terkait dan hal ini belum berjalan dengan optimal. Selanjutnya kajian mengenai monitorable yang dilakukan dalam rangka penyempurnaan indikator kinerja yang digunakan, ada kegiatan kontrol yang dilakukan lewat kegiatan monitoring dan evaluasi yang dilakukan secara rutin setiap triwulan sekali. Namun pelaksanaannya belum dapat berjalan dengan optimal, dilihat dari masih adanya permasalahan yang disebabkan oleh kurangnya dukungan informasi yang diberikan oleh pelayan kesehatan yang membuat proses perencanaan dan penganggaran yang ada belum berjalan dengan optimal.

\section{b. Kendala Dalam Penerapan Anggaran Berbasis Kinerja}

Pelaksanaan penerapan anggaran berbasis kinerja pada Dinas Kesehatan Kota Bandung jika dilihat dari beberapa informasi yang diperoleh dari beberapa narasumber telah dilaksanakan secara clear, relevant, economic, adequate dan monitorable namun dalam pelaksanaannya masih terdapat beberapa kendala yang dihadapi. Seperti masih terdapatnya permasalahan dalam kajian relevant akibat kurangnya anggaran yang tersedia. Adanya beberapa kegiatan kolaboratif dengan OPD lain pun menjadi salah satu hambatan yang ada, Kemudian kajian mengenai monitorable pun belum berjalan dengan optimal, yang diakibatkan oleh kurangnya dukungan informasi yang diberikan oleh pelayan kesehatan.

Selain permasalahan yang terdapat dalam beberapa kajian tersebut, terdapat juga beberapa kendala yang dihadapi oleh Dinas Kesehatan Kota Bandung dalam penerapan anggaran berbasis kinerja. Kendala ini berhubungan dengan kurangnya dukungan informasi yang diberikan oleh pelaku pelayan kesehatan mengenai informasi yang dibutuhkan dalam memenuhi indikator kinerja utama yang ada, sehingga membuat proses perencanaan dan penganggaran untuk tahun berikutnya terhambat. Kemudian kendala yang muncul juga berhubungan dengan dukungan dari sumber daya manusia yang belum optimal yang disebabkan oleh kurangnya kuantitas yang ada dalam memenuhi kegiatan dalam rangka penerapan anggaran berbasis kinerja, kemudian ketersediaan anggaran menjadi kendala nyata yang dihadapi instansi terkait dalam proses perencanaan dan penganggaran, kurangnya anggaran yang tersedia membuat belum semua kegiatan dapat dilaksanakan secara maksimal dalam rangka pencapaian tujuan yang hendak di capai. Kondisi lingkungan sosial dan ekonomi yang sering berubah yang meliputi perubahan pola penyakit di masyarakat serta perubahan harga di pasaran berpengaruh terhadap pelaksanaan kegiatan yang ada sehingga membuat kegiatan yang dilaksanakan sering kali tidak sesuai dengan apa yang direncanakan. Sering terjadinya error pada saat proses perencanaan dan penganggaran pun menjadi salah satu hambatan nyata yang dihadapi.

\section{c. Solusi Dalam Penerapan Anggaran Berbasis Kinerja}

Kendala yang dihadapi dalam penerapan anggaran berbasis kinerja tentu harus dapat dicarikan solusinya. Dengan adanya penerapan anggaran berbasis kinerja yang baik dapat berimplikasi langsung terhadap kinerja yang akan dilakukan nantinya. Karena pada dasarnya perencanaan dan penganggaran merupakan cerminan dari apa yang akan dilakukan oleh instansi tersebut. Namun beberapa kendala tersebut bukan berarti tidak dapat dicarikan solusinya, dengan semakin dioptimalkannya proses monitoring dan evaluasi tentu akan membuat setiap permalasahan yang ada dapat diatasi. Kemudian dengan adanya monitoring dan evaluasi yang dilakukan juga dapat menekan permasalahan yang muncul, apalagi dengan kegiatan monitoring dan evaluasi yang selalu dilakukan dalam triwulan sekali ini akan membuat perencanaan dan pelaksanaan anggaran berbasis kinerja akan lebih baik lagi. 
Penerapan anggaran berbasis kinerja yang telah running dalam beberapa tahun pun menjadi salah satu alasan positif dalam menangani setiap kendala yang muncul, karena pegawai dan staff yang ada pada Dinas Kesehatan Kota Bandung dapat menyesuaikan diri dengan sistem yang ada sehingga permasalahan penerapan anggaran berbasis kinerja dapat dicarikan solusinya.

Permasalahan yang muncul dalam penerapan anggaran berbasis kinerja juga dapat disebabkan oleh adanya proses perencanaan dan penganggaran yang dikejar waktu sehingga proses perencanaan dan penganggaran yang ada terkesan terburu-buru sehingga belum berjalan dengan optimal. Untuk mengatasi hal ini Dinas Kesehatan Kota Bandung telah melakukan perencanaan dan penganggaran sedini mungkin yang didasarkan atas pelaksanaan kegiatan tahun sebelumnya yang menjadi patokan pada tahun sebelumnya, sehingga sebelum tahun anggaran berakhir instansi terkait telah memiliki rancangan kegiatan serta anggaran yang akan dilakukan pada tahun berikutnya. Hal ini dilakukan dalam rangka meminimalisir kesalahan serta kekurangan yang disebabkan oleh adanya proses perencanaan dan penganggaran yang terkesan terburu-buru dan dikejar waktu.

\section{Simpulan}

Proses perencanaan dan penganggaran merupakan cerminan dari kegiatan yang akan dilakukan. Tentu proses ini harus dijalankan dengan baik agar dapat berdampak positif terhadap pelaksanaan kegiatan yang ada. Proses penganggaran pada organisasi publik dewasa ini telah berkembang menjadi konsep penganggaran yang berorientassi pada kinerja. Penerapan anggaran berbasis kinerja ada pada Dinas Kesehatan Kota Bandung telah dilaksanakan secara clear, relevant, economic, adequate dan monitorable. Meskipun masih terdapat beberapa kendala yang dihadapi yang membuat proses penganggaran belum berjalan dengan optimal. Kendala yang dihadapi dalam penerapan anggaran berbasis kinerja meliputi kurangnya dukungan informasi yang diberikan oleh pelayan kesehatan yang membuat proses penganggaran belum berjalan dengan optimal. Kemudian kurangnya anggaran yang tersedia, kondisi lingkungan sosial dan ekonomi yang sering berubah yang meliputi perubahan pola penyakit di masyarakat dan juga perubahan harga yang ada di pasaran, dan beberapa tugas kolaboratif dengan OPD lain seringkali membuat proses penganggaran belum berjalan secara optimal. Namun dengan telah berjalannya penerapan anggaran berbassis kinerja dalam beberapa tahun membuat pegawai serta staf yang ada telah mampu untuk menyesuaikan diri dengan kebijakan tersebut. Pengoptimalan monitoring dan evaluasi dalam penerapan anggaran berbasis kinerja menjadi salah satu cara yang dilakukan dalam menghadapi kendala yang ada.

\section{Referensi}

Anggara, S. (2015). Metode Penelitian Administrasi (Sahya Anggara (ed.); Pertama). CV Pustaka Setia.

Bastian, I. (2010). Akuntansi Sektor Publik Suatu Pengantar Edisi Ketiga (I. Bastian (ed.); Ketiga). Erlangga.

Dwiputrianti, S., Suharsini. (2012.). Terhadap Efisiensi, Efektifitas Dan Akuntabilitas Pada Pusat Pendidikan Dan Pelatihan Kementerian Dalam. 309-329.

Farida, A.S., Nugaraha, R.F.M. (2019). Analisis Laporan Keuangan Pemerintah Daerah Kabupaten Subang. Publica: Jurnal Pemikiran Administrasi Negara. 11 (2). DOI :10.15575/jpan.v11i2.7644 
Halim, A. (2007). Akuntansi Sektor Publik: Akuntansi Keuangan Daerah (A. Halim (ed.)). Salemba Empat.

Harun. (2009). Reformasi Akuntansi dan Manajemen Sektor Publik di Indonesia (Harun (ed.)). Salemba Empat.

Mardiasmo. (2009). Akuntansi Sektor Publik (Mardiasmo (ed.)). CV Andi.

Ningsih, S., Wirahadi, A., \& Fontanella, A. M. Y. (2019). Analisis Penerapan Anggaran Berbasis Kinerja dengan Konsep Money Follow Program Dalam Perencanaan dan Penganggaran Kota Padang. 13(1), 1-16.

Nordiawan, D., \& Hertianti, A. (2010). Akuntansi Sektor Publik (D. Nordiawan \& A. Hertianti (eds.). Salemba Empat.

Robinson, M., \& Last, D. (2009). Technical Notes and Manuals A Basic Model of Performance-Based Budgeting. 1-12.

Silalahi, U. (2012). Metode Penelitian Sosial (U. Silalahi (ed.)). Refika Aditama.

Tinangon, J. J. (2015). ISSN 2303-1174 M. G. Anton., J.J. Tinangon., I. Elim. Penerapan Anggaran. 4(17), 553-563.

Umam, K., Fadila, Y.I. (2019). Dampak Retribusi Jasa Umum Terhadap Pendapatan Asli Daerah Kabupaten Kuningan. Publica: Jurnal Pemikiran Administrasi Negara. 11 (2). DOI :10.15575/jpan.v11i2.7638 